\title{
An Eschatological Critique of Catherine Pickstock's Liturgical Theology
}

\author{
Grant, Euan Alexander
}

\begin{tabular}{|l|l|}
\hline Date of deposit & $13 / 09 / 2019$ \\
\hline Document version & Author's accepted manuscript \\
\hline Access rights & $\begin{array}{l}\text { C } 2018 \text { Provincial Council of the English Province of the Order of } \\
\text { Preachers. This work has been made available online in } \\
\text { accordance with publisher policies or with permission. Permission } \\
\text { for further reuse of this content should be sought from the } \\
\text { publisher or the rights holder. This is the author created accepted } \\
\text { manuscript following peer review and may differ slightly from the } \\
\text { final published version. }\end{array}$ \\
\hline $\begin{array}{l}\text { Citation for } \\
\text { published version }\end{array}$ & $\begin{array}{l}\text { Grant, E. A. (2019). An Eschatological Critique of Catherine } \\
\text { Pickstock's Liturgical Theology. New Blackfriars, 100(1089), 493- } \\
508\end{array}$ \\
\hline $\begin{array}{l}\text { Link to published } \\
\text { version }\end{array}$ & https://doi.org/10.1111/nbfr.12400 \\
\hline
\end{tabular}

Full metadata for this item is available in St Andrews Research

Repository at: https://research-repository.st-andrews.ac.uk/

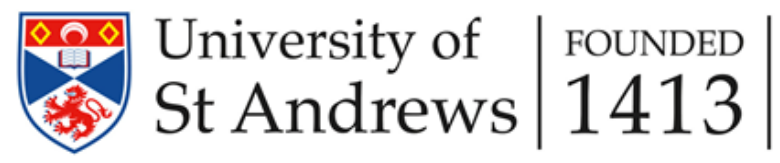




\section{An Eschatological Critique of Catherine Pickstock's Liturgical Theology}

\section{Introduction}

It is now two decades since the initial publication of After Writing, Catherine Pickstock's contribution to the founding documents of Radical Orthodoxy. In the meantime, what was then a dynamic and novel movement has broadened and, we might say, settled down somewhat, and space has opened for responses which are neither adulatory acclamations nor frontal assaults, but questions from those who, having learned much from Radical Orthodoxy, find it difficult to accept all of the various ways in which it has presumed almost to refound Christian theology as a whole in its own image.

It is in this spirit, then, that I propose here to demonstrate that the liturgical theology of Catherine Pickstock, as presented in After Writing, with its attempt to consummate and complete both philosophy and theology by an account of the old Roman liturgy, collapses eschatology into liturgy with the effect of effacing both the iterative and the consummative elements of the Catholic eschatological tradition. I understand this tradition to be expressed both magisterially and in the various early Christian liturgical traditions, which can be summarised as teaching that, because Christian eschatology is based on the redemption won in the Crucifixion, Resurrection, and Ascension of Christ, the history of the church inhabits a tension between the 'already' of God's victory over sin, and the 'not yet' of the final consummation of all things in Christ's second coming. ${ }^{1}$ It is this tension of 'already' and 'not yet' which will, in the first instance, structure the discussion of Pickstock's liturgical theology which follows. I will provide a close reading of Pickstock's liturgical account of time, human subjectivity, and worship, demonstrating the way in which this theme is prematurely erased in each aspect of her account of the liturgy.

In order to demonstrate the loss involved in this erasure, I will look first to the view of eschatology worked out in recent magisterial documents, a reasonable procedure, given the extent to which Pickstock's doctrinal materials, language, and conversation partners are all drawn from a Catholic

\footnotetext{
${ }^{1}$ Geoffrey Wainwright, Eucharist and Eschatology (London: Epworth, 1971), pp. 12ff.
} 
context. Even were this not the case, however, the Catholic tradition represents a number of traditional concerns which are by no means exclusively Roman in their roots in the historic Christian tradition.

Building on the doctrinal scheme presented by this body of teaching, and with reference primarily to the work of Joseph Ratzinger, I will demonstrate the possibility of an alternative construction of the relationship between the liturgy and eschatology, which does not collapse either unduly into the other. This will allow me to conclude that, while Pickstock's discussion contains valuable insights, her construal of various aspects of the liturgy fails to recognise the particular form of relativity which attends to all of these things in the present age by contrast with the eschatological age. Pickstock's response to 'postmodernity' leads her to accept certain relativities and ambiguities in the human condition as inherent to humanity, rather than as the conditions of human beings both fallen and in via, on the way to another sort of life in the Resurrection, the fullness of the Lord's presence in patria.

\section{The Lineaments of the Liturgical City}

Catherine Pickstock's high aims for her liturgical theology are clear in the quite remarkable opening sentence of After Writing. Much of the importance of her exuberant analysis of the old Roman Rite is to be found in the way her theory of transubstantiation (reiterated in the fifth part of The Radical Orthodoxy Reader) ${ }^{2}$ is held to finally overcome the 'nihilism' inherent in Jacques Derrida's deconstruction of a metaphysical tradition predicated on the duality of absence and presence. ${ }^{3}$ I do not intend to tackle the argument with Derrida directly. Instead, I wish to question the assumptions about the place of the liturgy in the total scheme of the human life with God which is Christianity which underpin Pickstock's counterargument. It may be that Derrida's criticisms of the metaphysical tradition are significant enough to require a full theological response, but such a response, to be properly theological and faithfully Christian, must, I argue, take into account the eschatological tension which Pickstock's account dissolves. To demonstrate that this is the case, let us begin with Pickstock's view of liturgical time.

\footnotetext{
${ }^{2}$ See Simon Oliver, introduction to Part V, and Catherine Pickstock, 'Thomas Aquinas and the quest for the Eucharist', in The Radical Orthodoxy Reader, ed. John Milbank and Simon Oliver, (London: Routledge, 2009), pp. $261 \mathrm{ff}$.

${ }^{3}$ Catherine Pickstock, After Writing: On the Liturgical Consummation of Philosophy, (Oxford: Blackwell, 1998), p. 253.
} 


\section{Liturgical Time}

Pickstock ruminates on the time of the liturgy in a number of places, but focussed discussion begins in 'Seraphic Voices. ${ }^{4}$ In what seems to be an instance of eschatological orientation, the 'openness' of liturgical time is understood as the 'anticipatory prelude of post-temporal fulfilment' because it proceeds through the Liturgy as a continuous "non-identical "return." 5 The symbolic expression of this claim in the rite itself is found in the motif of evening sacrifice in the prayers for the censing of the altar at the Offertory. Pickstock picks up on the ancient Jewish idea in which a day begins not with its own morning but with the falling darkness of the preceding evening. If the liturgy is to be understood as a sacrificium vespertinum in this sense, then the time of the liturgy is "forever "before", 6 the 'day' which it inaugurates and anticipates. This symbolises (and therefore ensures) that no action which is connected to the time of the liturgy 'stands on its own, outside an anticipation of its ultimate eschatological consummation. ${ }^{7}$ A similar theme of the anticipatory nature of liturgical time is also drawn out by the fact that the remembrance commanded at the Last Supper is itself an anticipation of the Crucifixion yet to come. ${ }^{8}$

In itself, this discussion relates the symbolic action of the liturgical prayers admirably to the 'not yet' of eschatological expectation. Pickstock's treatment of this theme becomes problematic, however, as the distinction between this 'not yet' and the redemptive 'already' seems to be effaced. The first hints of this problem appear in the discussion of the liturgical 'gift' both offered and received in the Canon. This gift, first of all the gift of praise of the Sanctus and the Preface, 'confers space and time upon themselves, at the very moment when the proximate community joins the angelic celebration. ${ }^{9}$ For Pickstock, the liturgy is the measure of all creation, and since the liturgical gift of praise is to be offered semper et ubique, liturgical time measures all time and gives it its specificity by contrast. This means that 'The place and time in which it is right to offer praise are transgressive and eschatological: all places and all times. ${ }^{10}$

What it means for time to be eschatological in this sense, however, is quite different to that which animates Pickstock's discussion of eschatological anticipation. If time is eschatological because it is

\footnotetext{
${ }^{4}$ Ibid., p. $220 \mathrm{ff}$.

${ }^{5}$ Ibid., p. 221.

${ }^{6}$ Ibid.

${ }^{7}$ Ibid.

${ }^{8}$ Ibid., p. 223.

${ }^{9}$ Ibid., p. 235.

${ }^{10}$ Ibid.
} 
related to the eternity of God, which is equally present to all times, then eschatology is being assimilated to participation in eternity, and quite possibly at the expense of reference to the futurity presupposed by the 'not yet' of the Gospels. While these two themes are capable of standing together, the way in which Pickstock extends her treatment raises a number of concerns.

Pickstock understands the gift of praise which we offer in the Sanctus to be an instantiation and aspect of the central liturgical gift of peace which we receive from God and which is enacted and exchanged at the Pax. This liturgical gift-action has no lesser effect than the 'pacification' of 'immanentist time.' Time 'construed as spatial and linear' is understood as the essence of evil from which we pray to be released. ${ }^{11}$ The gift of peace, on the other hand, inaugurates a 'redemptive exchange between past, present, and future,' which is also 'the (always arriving through time) gift of (spatial) community. ${ }^{12}$ Combining this line of argument with the claim that 'the request for peace can only be made authentically from within peace, from within the heavenly realm which we now do not merely impersonate, ${ }^{13}$ it seems reasonable to suggest that Pickstock is proposing that the worshippers, by their participation in the liturgy, cease to be part of the present 'evil age,' but are incorporated as a community into the eschatological age to come.

If this is so, then it is important to ask whether such a 'turning time into peace' ${ }^{14}$ so strongly emphasises the 'already' (while denying the existence of the 'local present moment') ${ }^{15}$ that it effaces the possibility of the 'not yet' and tends to vitiate Pickstock's eschatological gestures. In terms of Pickstock's discussion of time per se, this question is difficult to unpick (partly because, if I read her correctly, she does not allow for any understanding of time which is not the measure of the process of the existence of human subjectivity - however that is construed), but since a very similar structure is inherent in her treatment of the themes of the subject and of worship, it is possible to answer the question of time within this broader context.

\footnotetext{
${ }^{11}$ Ibid., p. 237.

${ }^{12}$ Ibid.

13 Ibid., p. 238

14 Ibid., p. 237.

15 Ibid.
} 


\section{The Liturgical Subject}

For Pickstock, the liturgical subject is the truly human subject. Her account of this subject proceeds on the basis of a critique of the modern understanding of the subject, and its dissolution in postmodernity, in which the fundamental problem of the modern subject is 'the insistence of autonomy and self-identity. ${ }^{, 16}$ Modernity, she claims, is able to understand the subject only as an atomistic selfidentity securing itself by interaction with a world of controllable objects. Such a subject, however is ultimately reducible to the postmodern subject wholly under the control of and dissolved into that language by which it seeks to manipulate the world but which remains forever beyond its command. This subject, by being totally emptied of any self-continuity whatsoever, is 'reducible to the selfidentity of indifference, and the supreme objectivity and continuity of the nihil. ${ }^{17}$

Pickstock completely accepts the effectiveness of this postmodern reduction over against the modern account, and so her liturgical construction of the subject is required to demonstrate that all of the moves which postmodernism makes can equally be construed in Christian terms: '[the subject's] endless permutations and borrowings [become] redemptively and analogously different. ${ }^{18}$ This construal requires two efforts: first, to demonstrate that the liturgy has already done what the postmodern deconstruction of the subject set out to do (and if possible, that it has done it even more thoroughly); second, to demonstrate the salvific nature of the deconstruction in the liturgical as opposed to the nihilist case.

The first effort is undertaken in Pickstock's contrast of Homeric and liturgical characterisations: unlike the static character of the Homeric hero, the liturgical subject is taken to borrow its identity from various sources: particularly the name of the Trinity in the opening In Nomine ${ }^{19}$ and the worshipping angels of the Gloria $^{20}$ (in their 'shifting and ambiguous space beyond our own'). ${ }^{21}$ Unlike the static epithets of Homeric heroes, the language of the liturgy under-determines the worshipper and casts him or her in a variety of shifting roles. This is not only the case for the worshipper, but also for God, who is identified, in Pickstock's reading of the Gloria and the Credo, as much as the human subjects of the liturgy by the ambiguity of his naming and identity. ${ }^{22}$ The Roman Rite, then, has already accomplished

\footnotetext{
${ }^{16}$ Ibid., p. 199.

${ }^{17}$ Ibid.

${ }^{18}$ Ibid.

${ }^{19}$ Ibid., p. 183.

${ }^{20}$ Ibid., p. 188.

${ }^{21}$ Ibid., p. 177.

${ }^{22}$ Ibid., particularly p. 204.
} 
what Derrida set out to do, in constituting the subject by the ambiguity of a series of borrowings, supplementations, and deferrals.

The second move in Pickstock's account is to claim that this ambiguity creates an "“analogical" identity. ${ }^{, 23}$ For human worshippers, the vocal form of apostrophe breaks down the 'immanentist' order of objects, totally at hand and at our disposal, and empties out our subjectivity before the absent God. This process is what allows us to know ourselves as constituted an 'I' by our prior address as God's 'thou,' and allows us to take on a 'non-ironic, non-indeterminate subjectivity' ${ }^{24}$ because the 'objective' is thus grounded in a transcendent subjectivity. The subject which is grounded in this way is defined primarily by being open to potential, because God's various liturgical characterisations reveal 'the zenith of differential continuity to reside in [him]. ${ }^{25}$ Since the ambiguity which characterises the worshipper resides in God to the highest degree, ${ }^{26}$ 'the alterations which the worshipper undergoes are not to be seen as a dissipation of character into a nihilistic explosion of differences, nor as a separation of the subject from his position in the world, but rather as a perpetual fulfilling of the very possibility of character in and through a transfiguration and intensification of the world as such. ${ }^{, 27}$ That which ensures the dissolution of the subject in postmodernism is its root in the divine for Pickstock.

What is the relation between this liturgical construal of subjectivity and human life as understood eschatologically? Pickstock insists upon the necessity of an 'eschatological reserve, or continuing acknowledgement of the impossible and the need for repeated divine arrival ${ }^{28}$ in the liturgical construction of the subject. The treatment of the theme, however, suggests that this eschatological 'reserve' is constitutive not because it looks forward to something more or some different state from what is constitutive of human subjectivity under the conditions of the present age, but because it ensures that the openness of that subjectivity is perpetually maintained: 'the partial arrival of liturgy... is one and the same with the attainment of a definite but open identity by the subject. ${ }^{29}$ If the fullness of God's presence is understood not as the resolution of the perpetual deferral and ambiguity of human subjectivity, but as its highest instance and, in that sense alone, its ground, then there is no sense in which we can 'come into ourselves' in the eschaton in a way which finally exceeds the form of

\footnotetext{
${ }^{23}$ Ibid., p. 178.

24 Ibid., p. 197.

25 Ibid., p. 208.

${ }^{26}$ In Pickstock's discussion of the Gloria this is implicitly related to the doctrine of the Trinity: 'It is almost as if the persons of the Trinity borrow or swap nominations in order to fulfil their identifications.' Ibid., p. 204.

${ }^{27}$ Ibid., p. 212.

28 Ibid., pp. $214 \mathrm{f}$.

${ }^{29}$ Ibid., p. 214.
} 
subjectivity which pertains to us in the present age. Noting the structural similarity of this interpretation to that which Pickstock advances concerning liturgical time, the suggestion that the eschatological 'not yet' is swallowed up in the liturgical 'already' (indeed, that it is precisely this supposed 'reserve' which is constitutive of the 'completed' character of the 'already') is clearly supported by Pickstock's view of liturgical subjectivity. This position can be finally solidified by a consideration of Pickstock's theology of worship.

\section{Liturgical Worship}

The clearest expression of Catherine Pickstock's theology of worship is developed under the image of a journey. ${ }^{30}$ Worship is a journey of a very particular kind, because it is one whose destination continually recedes before it; indeed, it is a journey which cannot even continue, but can only always be beginning. Yet, in consequence of this, it is also a journey for whom continually beginning again is also a form, indeed, the paradigmatic form, of arriving. This imagery is introduced in the discussions of the In Nomine which begins the rite, and developed in the characterisation of the altar. It is also the form of thinking which grounds the continuous understanding of prayer as 'prayer that there might be prayer' and thus Pickstock's view of the benign deferral of liturgical language. Finally, it is the expression in the form of imagery of the thought-form which underlies, as suggested above, Pickstock's construal of both liturgical time and the liturgical subject.

Following her introduction of the journey theme in the opening invocation of the Trinity as defining the worshipper as 'he who travels within (the name of) that which he travels towards, ${ }^{31}$ Pickstock picks up the question of the altar which (Introibo ad altare Dei) is named as the destination of the liturgical journey. Pickstock declares that '[u]nlike ordinary geographical destinations, the altar of God is an infinitely receding place, always vertically beyond.' 32 This introduces the conception of the liturgy as always an anticipation of worship which cannot yet begin: 'Our liturgy in time can only be the Liturgy which we render in order to be able to render liturgy. ${ }^{33}$ The reference to liturgy in time might seem to suggest a gesture towards eschatological resolution, but Pickstock's discussion of the following antiphons reveals that resolution actually lies in the journey itself, because Christ has

\footnotetext{
${ }^{30}$ See, e.g., ibid., p. 181.

${ }^{31}$ Ibid., p. 183.

${ }^{32} \mathrm{Ibid}$.

${ }^{33}$ Ibid.
} 
become incarnate and so transformed the 'bad infinite' ${ }^{34}$ of our sinfulness and consequent distance from God into the space of God's presence. The way of the liturgical journey is consequently identified wholly with the altar, and so, 'to begin is to arrive, and the way is the goal. ${ }^{, 35}$ This reduction does not deny the movement in Pickstock's account of the liturgy, it merely suggests that the eschatological tensions towards which Pickstock gestures at various points in her account resolve themselves not, in fact, in the eschatological sphere, but wholly within the liturgical sphere of the present age.

This reduction is continued in Pickstock's discussion of the penitential aspects of the rite: once again a bad infinite is overcome by the 'putting on' of Christ in the Kyrie, and we are enabled to pray 'to be able to pray. ${ }^{36}$ In precisely the same way, apostrophe is that rhetorical form of calling 'which enables

the worshipper to call out in the first place. ${ }^{37}$ The theme returns again in a number of places, ${ }^{38}$ and its full significance is brought out by consideration of the theme of gift which has so much importance for the constructive side of Pickstock's account. Ultimately, Pickstock's ontology of divine gift admits of no degrees, but is in fact a binary system: one can be within the gift economy or outside it. 'To be within the gift, to give or receive at all, is to be within peaceful perfection, to reside within the Trinity. ${ }^{39}$ Thus the eschatological tension is finally collapsed wholly into a liturgical resolution.

\section{Magisterial Treatments of the Theme}

Catherine Pickstock's account of the 'lineaments of the liturgical city' issues, then, in the reduction of the eschatological to the liturgical. So far, this has been criticised primarily as a failure to give due weight to the general contrast of 'already' and 'not yet' which exegesis has found in New Testament eschatology. In developing a more concrete critique, I will begin with the magisterial documents which have followed on from the declarations of the Second Vatican Council. ${ }^{40}$ While a certain reduction of eschatology in Roman Catholic academic theology has occurred since the Council, this contrast is not clearly rooted in the conciliar documents themselves.

\footnotetext{
${ }^{34}$ Ibid., p. 185.

35 Ibid.

${ }^{36}$ Ibid. p. 187.

${ }^{37}$ Ibid. p. 194.

${ }^{38}$ Particularly in the treatment at ibid., p. 246.

${ }^{39}$ Ibid., pp. $250 \mathrm{f}$.

40 This might, perhaps, be called the lineaments of the Vatican City.
} 
On eschatology generally, Lumen gentium offers the theme of the Pilgrim Church, which proclaims a futurist eschatology in which the saving work of Christ is carried on by the Holy Spirit in the Church, all tending towards the renewal of the world and the consummation of salvation following the second coming of Christ. ${ }^{41}$ The traditional scheme of post-mortem but pre-judgement purgation and bliss is also retained, with an accent on the role of the saints, who are held to be most closely united with the church on earth in the celebration of the liturgy. ${ }^{42}$ The language of Lumen gentium on eschatology 'events' is, not without reason, something of a biblical pastiche, and so susceptible (like certain articles of the creed) to interpretation more in figurative than in literal terms. ${ }^{43}$ Gaudium et spes, by contrast, deploys little biblical or figurative language in its discussion of death, but does promise the overcoming of bodily death by Christ's resurrection, ${ }^{44}$ while Sacrosanctum concilium reiterates the traditional theme of the liturgy as a foretaste of heavenly worship. ${ }^{45}$

The conciliar documents, then, do not offer any radical revision of the traditional eschatological schemata, and the focus which Monika Hellwig sees in contemporary Roman Catholic eschatology on 'the realization of the promised reign of God in all human experience" ${ }^{46}$ is most charitably seen as the result of a broader communitarian and pastoral accent in the works produced by the council generally. The traditional themes of Catholic dogmatic thinking are, however, forcefully reiterated in a letter of the Congregation for the Doctrine of the Faith published in 1979, which affirms, inter alia, bodily resurrection, the immortality of the soul, a distinction between the state of human beings immediately following upon death and the 'glorious manifestation of our Lord Jesus Christ,' and a balance of the continuity of earthly and heavenly charity with a 'radical break between the present life and the future one, due to the fact that the economy of faith will be replaced by the economy of the fullness of life. ${ }^{47}$

When it comes to the specific connection between the Eucharist and eschatology, the Catechism of the Catholic Church adds some further nuance. The liturgy is to be seen not only as a foretaste of but a journeying towards the heavenly worship, ${ }^{48}$ in which the Spirit 'hastens' the consummation of

\footnotetext{
${ }^{41}$ Lumen gentium $\S 48$.

42 Ibid., § 49.

${ }^{43}$ As is suggested by Monika K. Hellwig, 'Eschatology', in Systematic Theology: Roman Catholic Perspectives, ed. Francis Schüssler Fiorenza and John P. Galvin (Dublin: Gill and MacMillan, 1992), p. 683.

${ }^{44}$ Gaudium et spes, $\S 18$.

${ }^{45}$ Sacrosanctum concilium, $\S 8$.

${ }^{46}$ Hellwig, 'Eschatology', p. 674.

${ }^{47}$ Congregation for the Doctrine of the Faith, 'Letter on Certain Questions Concerning Eschatology', May 17, 1979, accessed May 4, 2014, http://www.vatican.va/roman_curia/congregations/cfaith/documents/rc_con_cfaith_doc_19790517_escatologia_en.html ${ }^{48}$ Catechism of the Catholic $\bar{C}$ hurch $\S \S 1090,1344$.
} 
salvation. ${ }^{49}$ It is important to note that the heavenly liturgy, as in the letter of the Congregation for the Doctrine of the Faith, is discontinuous with the earthly, since the former is celebrated without signs and is 'wholly communion and feast." ${ }^{50}$ Likewise, the presently veiled presence of Christ is to be contrasted with the full vision which is to come. ${ }^{51}$

The magisterial form of Catholic theology, then, promulgates a view of eschatology based centrally in the biblical and creedal testimony to both the resurrection of Christ and the promise of his future second coming, but extended by consideration of the state of the saints and the consequent necessity of conceiving of the 'soul' as continuing its existence after death. In the sphere of the liturgy, while affirming wholly the presence of Christ in the sacrament, it affirms that the Second Coming introduces a new modality of worship in which sacramental signs are exceeded by a radically new mode of divine presence. This radical break calls into question Pickstock's tendency to dissolve the eschatological into the liturgical; the iterative vision of human life moving towards bliss through a progressive purification, the doctrine of Purgatory, is also significantly resistant to the binary between peace as perfect realised gift, and exterior violence. The magisterial tradition, then, does not allow for a full adoption of the scheme proposed by Pickstock.

\section{The Catholicity of the Magisterium}

One possible - I do not say wise or acceptable - response at this point would be, of course, to ignore the magisterial teachings. It might be suggested that it develops a uniquely Roman Catholic attitude, developed idiosyncratically on the basis of an arbitrary assumption of authority. Alternatively, one might accept that Rome promulgates a broadly ecumenically acceptable attitude, but that this merely relocates the problem. One could claim that, however broadly they are accepted, the tensions

propounded by the magisterial teaching are insurmountable, that one of liturgical fulfilment or eschatological reserve must collapse into the other, and that Pickstock's contribution remains of great value in presenting a fluent and attractive presentation of the former.

Beyond noting the thoroughly scriptural basis of the magisterial treatments cited, however, he charge of extrinsic authoritative imposition can be answered by looking again to Geoffrey Wainwright's

\footnotetext{
49 Ibid., $§ 1107$.

${ }^{50}$ Ibid., $§ 1136$.

51 Ibid., $\$ 1404$.
} 
remarkably broad-ranging study of the eschatological dimension of the Eucharist. Wainwright, despite coming to doctrinal conclusions on intercommunion and the Real Presence which differ markedly from those of the Vatican congregations, demonstrates that many of the fundamental themes of the magisterial account, particularly on the eschatological side, are broadly ecumenical positions embraced throughout the history of the Christian tradition.

In this regard, Wainwright is useful first in balancing some over-zealous Catholic interpretations of the Eucharist which, in conflating the New Testament 'Kingdom of God' wholly with the Church (particularly following P. Benoit's exegesis of Luke 22.15-18), make it simply and unambiguously the messianic banquet of the kingdom. ${ }^{52}$ Such a reading of Luke must be balanced by the different emphases of the institution accounts in Matthew, Mark, and Paul. The 'already/not yet' schema means that 'There is no exclusive alternative between the eucharist as fulfilment of the signs of Jesus' ministry and the eucharist as itself a sign still of the meal of the kingdom. ${ }^{53}$ This balancing of themes, itself consonant with the Catholic understanding, is also brought out in the discussion of the Eucharist as remembrance of Christ as the one who promised to come again, ${ }^{54}$ and of communion as the 'earnest' of the hope of that second coming. ${ }^{55}$ Equally, the progressive nature of liturgical life is brought out in the early (and Eastern as much as Western) images of the Eucharist as food for eternal life and the medicine of immortality, continuously transforming the reality of the worshipper who partakes of them. ${ }^{56}$

In fairness to Pickstock's close reading of the pre-reform Roman Rite, however, it is notable that prior to the post-conciliar reforms, the Parousia was almost entirely absent from the liturgy of the West, especially by comparison with its inclusion in the Eastern anamneses. ${ }^{57}$ Outside of the Creed, and the Prefaces of Advent, the futurity of the western liturgy was confined to a temporally-indeterminate future judgement. ${ }^{58}$ Louis Bouyer points out, however, that this focus on the Parousia in Advent makes sense in the preparation for Christmas, since eschatological hope is not simply satisfied by the birth of Christ, but brought to its highest pitch of clarity and intensity, and so that the liturgical placement of those references reinforces rather than collapses the eschatological tension inherent in the liturgy. ${ }^{59}$

\footnotetext{
52 Wainwright, Eucharist and Eschatology, p. 39.

${ }^{53}$ Ibid., p. 41.

${ }^{54}$ Ibid., p. 67.

55 Ibid., p. 92.

${ }^{56}$ Ibid., pp. $111 \mathrm{f}$.

${ }^{57}$ Ibid., p. 88.

58 Ibid., n. 285.

${ }^{59}$ Louis Bouyer, Life and Liturgy, Stagbook edition, (London: Sheed and Ward, 1962), pp. $203 \mathrm{f}$.
} 


\section{The Consistency of the Account}

If the declarations are not, after all, totally offensive to a broadly ecumenical theological spirit, we are still able to ask to what degree all that is affirmed by them hangs coherently together. Here the contributions of Joseph Ratzinger are helpful.

What is brought out most convincingly in the account of the traditional eschatological topoi developed in Ratzinger's Eschatology ${ }^{60}$ is the thoroughgoing christocentrism which underlies even such apparently unbiblical developments as the doctrine of purgatory. From the continuity of the pre-Easter with the post-Easter kerygma onwards, ${ }^{61}$ the underlying theme of all Christian thought about life and death is communion with Jesus. This is continuous with the Old Testament development of the presence of the life-giving God of Israel, ${ }^{62}$ and results in a view of the Christian life which is centrally 'sharing in the martyria of Jesus by that dying which is faith and love. ${ }^{63}$

From this view of the Christian life, it is possible to understand the eschatological affirmations of the magisterium as a wholly consistent development of christological principles. More than anything else, it is communion with Christ which makes the 'decisive difference' beyond the opposition of biological death and life. ${ }^{64}$ Even the unfashionable understanding of the 'life' of the immortal soul after death must be understood as an expression of that openness to God which, once granted in baptism, only sin can remove. ${ }^{65}$

Consequently, with regard to the relation of eschatology and the liturgy, Ratzinger is able to affirm that, on the basis of the dual coming of Christ, the liturgy displays the 'interweaving of present and future which constitutes the specific mode of Christianity's presence in the world and its openness to what is to come. ${ }^{66}$ Because it is predicated on an acknowledgement of the distinction between Christ's presence to us now and the full revelation of his glory in the Parousia, this statement is not subject to

\footnotetext{
${ }^{60}$ Joseph Ratzinger, Eschatology: Death and Eternal Life, $2^{\text {nd }}$ ed., trans. Michael Waldstein, ed. Aidan Nichols (Washington, D.C.: Catholic University of America Press, 1988).

${ }^{61}$ Ibid., p. 35.

${ }^{62}$ Ibid, pp. 90ff.

${ }^{63}$ Ibid., p. 100.

${ }^{64}$ Ibid., p. 126.

${ }^{65}$ Ibid., pp. $155 \mathrm{f}$.

${ }^{66}$ Ibid., p. 203.
} 
the same unravelling as Pickstock's eschatological gestures, and on this basis Ratzinger can even say: 'Every Eucharist is Parousia, the Lord's coming, and yet the Eucharist is even more the tensed yearning that he would reveal his hidden glory.' 67

This theme of the distinction between Christ's sacramental and ecclesial presence and his eschatological presence is expanded in The Spirit of the Liturgy, by way of a threefold taxonomy drawn from Hebrews and the Fathers: the Old Testament prefigures the coming of Christ as 'shadow,' while Christ himself, in his life on Earth and in the Eucharistic presence, presents to us the true 'image' of God; the full 'reality' of God which we seek to enjoy, however, will only be available to us in the eschatological age following Christ's second coming. ${ }^{68}$ This scheme is also explored by Wainwright, who notes that Hebrews 6.5 allows for the 'tasting' of that coming reality, presumably in the Eucharist. ${ }^{69}$ This connection is also brought out by Ratzinger in relation to the traditional symbolism of Sunday as both the first and the eighth day inaugurating, as the day of the Resurrection, the new creation. ${ }^{70}$ Along with the other perennial practices of Christian prayer, orientation and kneeling, ${ }^{71}$ the forms of the liturgy and of Christian prayer are as expressive as explicit theology of the eschatological situation of the present time between the ages and of the anticipation of the fullness to come which forms the thinking of the magisterial documents. The significance of this account is that it allows us to overcome the possible difficulty of seeing different 'degrees' of divine presence if it is acknowledged that the Eucharistic presence is indeed the 'Real Presence' and yet is not also the final and definitive presence of divinity.

Ratzinger presents, then, an alternative understanding of liturgical temporality based on the modality of Christ's presence. While for Pickstock, God's presence as gift is binary and absolute precisely because it is also the presence of a God who - to overcome the Derridean deconstruction predicated on a distinction of presence and absence $^{72}$ - must also be totally absent, for Ratzinger the consummation of the presence of God still lies in the future, but is revealed and partaken of now by means of the perfect image which is Jesus' humanity. This thoroughly Chalcedonian account allows for an understanding of God's real presence under sacramental signs which does not obliterate the

\footnotetext{
67 Ibid.

${ }^{68}$ Ibid., p. 54.

${ }^{69}$ Wainwright, Eucharist and Eschatology, p. 11.

${ }^{70}$ Ratzinger, Spirit of the Liturgy, 97. See also ibid., pp. 76f.

${ }^{71}$ Ratzinger, Spirit of the Liturgy, pp. 69ff., 196. See also Wainwright, Eucharist and Eschatology, pp. 79f.

72 Pickstock, 'Thomas Aquinas and the quest for the Eucharist', p. 269.
} 
hope for a decisively new and final presence of God following on the second coming and the general Resurrection.

This understanding of time fundamentally informs both Ratzinger's theology and his anthropology. Since the eschatological schema is the basic temporal shape of our existence with God, it is impossible to abstract the true nature of human being from the question of its eschatological fulfilment. On the question of the eschatological constitution of the subject, Ratzinger's treatment of the exitus/reditus theme crystallises the temporal nature of the relation of our true subjectivity to God's creative goodness. In the reditus of creation, 'the coming-into-its-own of the creature answers back in freedom to the love of God [and so]... becomes wholly what it is precisely in giving itself. ${ }^{, 73}$ Here the theme of continuity and progress in the spiritual life which is so fundamentally catholic breaks through in a far deeper way than in Pickstock's binary division of gift economy and immanentist violence. Because charity is the essence of true life both in the world and in the coming kingdom, ${ }^{74}$ our subjectivity finds its formation and growth in the liturgical life in such a way that it is still ordered towards post-mortem purification and its final consummation in the general resurrection and the vision of God.

\section{Conclusion}

So far, I have demonstrated that there is a deep disparity which, despite initial appearances, exists between Catherine Pickstock's reading of the Roman Rite and the Catholic tradition of eschatological reflection. This tradition is neither arbitrary and authoritarian nor senseless and unstable. Given such a disparity, we are faced with the deferred question of whether there is any reason to prefer this account to the account provided by Pickstock. Quite apart from the question of tradition and authority, I believe that Pickstock's essay is difficult to accept even on its own terms.

Pickstock positions her essay not merely as a possible alternative to postmodern nihilism, but as its overcoming and defeat by a recovery of a liturgical understanding of language and so of reality. ${ }^{75}$ If, however, her understanding of the liturgy neglects or falsifies the eschatological concerns which animated not only the performance of the rite itself but also the theological accounts (particularly of

\footnotetext{
73 Joseph Ratzinger, 'The End of Time', in The End of Time? The Provocation of Talking about God, ed. Tiemo Reiner Peters and Claus Urban, trans. J. Matthew Ashley, (New York: Paulist, 2004), pp. $20 \mathrm{f}$.

${ }^{74}$ As in the CDF's 'Letter on Certain Questions Concerning Eschatology'.

${ }^{75}$ Pickstock, After Writing, p. xv.
} 
transubstantiation) which were developed to explain it, then her Eucharist is not so much a recovery as an invention. Even standing in total disagreement with much of his essay 'After Transubstantiation,' George Pattison's question is apposite:

On what grounds would we distinguish between a truly theological revivification of transubstantiation and a purely postmodern game, in which the term comes to be used at will for whatever purpose the particular theorist concerned wants? Could there be any grounds other than the fact of accepting the Eucharistic practice of the Roman Church itself? ${ }^{76}$

If Pickstock's account is to stand outside the conversation which presupposes the postmodern conclusions of total linguistically-reduced indeterminacy manipulated as a form of intellectual play, then it must be read in some other context of meaning, which is capable of withstanding this reduction. If in the appropriation of the Catholic theological tradition to this end, however, the cardinal eschatological direction of that tradition is effaced, then the argument which it appropriates is a culpable form of that nihilistic postmodern play which it seeks to avoid. Since Pickstock's essay does efface eschatology in this way it is unable to complete and surpass philosophy because it fails to be sufficiently conscientious and attentive as theology.

${ }^{76}$ George Pattison, 'After Transubstantiation', in Deconstructing Radical Orthodoxy, ed. Wayne J. Hankey and Douglas Hedley, (Aldershot: Ashgate, 2005), p. 152. 


\section{Bibliography}

1. Bouyer, Louis. Life and Liturgy. Stagbook edition. London: Sheed and Ward, 1962.

2. Catholic Church. Catechism of the Catholic Church. London: Geoffrey Chapman, 1994.

3. Congregation for the Doctrine of the Faith. 'Letter on Certain Questions Concerning Eschatology.' May 17, 1979. Accessed December 18, 2014.

http://www.vatican.va/roman_curia/congregations/cfaith/documents/rc_con_cfaith_doc_19790517_es catologia_en.html

4. Hellwig, Monika K. 'Eschatology.' In Systematic Theology: Roman Catholic Perspectives. Edited by Francis Schüssler Fiorenza and John P. Galvin. Dublin: Gill and MacMillan, 1992.

5. Milbank, John, and Simon Oliver, eds. The Radical Orthodoxy Reader. London: Routledge, 2009.

6. Pattison, George. 'After Transubstantiation.' In Deconstructing Radical Orthodoxy. Edited by Wayne J. Hankey and Douglas Hedley. Aldershot: Ashgate, 2005.

7. Pickstock, Catherine. After Writing: On the Liturgical Consummation of Philosophy. Oxford: Blackwell, 1998.

8. Ratzinger, Joseph. 'The End of Time.' In The End of Time? The Provocation of Talking about God. Edited by Tiemo Reiner Peters and Claus Urban, trans. J. Matthew Ashley. New York: Paulist, 2004.

9. Ratzinger, Joseph. Eschatology: Death and Eternal Life. $2^{\text {nd }}$ edition. Translated by Michael Waldstein. Translation edited by Aidan Nichols. Washington, D.C.: Catholic University of America Press, 1988.

10. Ratzinger, Joseph. The Spirit of the Liturgy. Translated by John Saward. San Francisco: Ignatius, 2000.

11. Second Vatican Council. Gaudium et spes. In Vatican Council II: The Conciliar and Post Conciliar Documents. 1981 edition. Edited by Austin Flannery. Leominster: Fowler Wright, 1981.

12. Second Vatican Council. Lumen gentium. In Vatican Council II: The Conciliar and Post Conciliar Documents. 1981 edition. Edited by Austin Flannery. Leominster: Fowler Wright, 1981.

13. Second Vatican Council. Sacrosanctum concilium. In Vatican Council II: The Conciliar and Post Conciliar Documents. 1981 edition. Edited by Austin Flannery. Leominster: Fowler Wright, 1981.

14. Wainwright, Geoffrey. Eucharist and Eschatology. London: Epworth, 1971. 